\title{
Utilization of Safe Motherhood Services, Effects of Male Involvement Study of Ilesa East Local Government, Osun State
}

\author{
Article by Omolola Oluwakorede Ademuyiwa, Okimi Olagoke Peter, Obayori \\ Olufunke, \\ Federal Teaching Hospital, Ido Ekiti, Nigeria \\ Email:koredemma@yahoo.com
}

\begin{abstract}
The study focused on the male involvement in utilization of safe motherhood services of their spouses in Ilesa East Local Government, Osun state. It assessed the level of married men's involvement in ante, intra and post-partum health care, the relationship between selected demographic factors and a review of identified barriers to safe motherhood services utilization. It also examined the barriers to male involvement in maternal health care in Ilesa East Local Government.

A cross-sectional descriptive design was employed using a semi structured questionnaire to gather information from 500 married men with at least one child. A multi stage sampling procedure was employed. Data was collected using interviewer administered questionnaire. Analysis of data was done using appropriate descriptive and inferential statistical techniques.

The results of the study revealed that about $85 \%$ of respondents were less than 55 years of age, majority of them (92.6\%) were of Yoruba ethnicity and were predominantly Christian (74\%). About $40 \%$ of them had tertiary education with over $60 \%$ in monogamous relationship. Majority (60.2\%) have between 1 and 4 children with $65 \%$ of respondents having a last child less than 4 years of age. Also, 362 (72.4\%) of respondents were well involved in Maternity care services, while 138 (27.6\%) were partially involved; none of the respondents was not involved in maternity care services. Also, majority of respondents agree with the named role of men in safe motherhood services at the prenatal level. The highest proportion of agreement was with regards to "Ensuring that the pregnant mother gets proper antenatal care" (97.8\%), while the lowest proportion was obtained with regards to "learning the symptoms of imminent delivery and of delivery complications" (66.2\%). Most (93.2\%) of the respondents support ensuring that their children receive all the needed immunization and $6.8 \%$ did not support it as the role of men. Furthermore, majority supported the role of men in family planning. In addition, $86.2 \%$ supported "Helping mothers to use modern methods correctly" while, 68.8\% supported the role of men in "Preventing unintended or unwanted pregnancies". The respondents supported factors identified as barriers to male involvement in maternity care services and were able to name: Financial constraint, Poor health of husband and Ignorance as factors hindering them from participation in maternal care. No statistically significant relationship was obtained between each of age, religion and ethnicity and level of involvement of men in maternal care. However the relationship between educational status and level of involvement in maternity care was statistically significant. Also, there was a significant relationship between number of wives and the level of involvement in maternal care among men. $(P=0.001)$.
\end{abstract}

\section{Introduction}

\subsection{Background of study}

The most populous country in Africa is Nigeria (Engender health 2009) with more than 140 million people (Fatima 2001). Additionally, the country accounts for a high percentage of infant and maternal mortality rate globally (75 infant deaths per 1,000 live births, 545 maternal death per 100,000 live births) (NDHS 2008) 145 women of child bearing age die daily from causes that are preventable (allAfrica.com, 2009). 
Generally women remain at home more than men (Feyisetan et al. 2000). According to MDG report of 2009, the population of women in paid employment, globally, outside the agricultural sector has increased marginally over the years while in Southern Asia, Northern Africa and Western Asia, employment opportunities for women remain overtly low. Also, there is poor representation of women in non-agricultural employment in sub-Saharan Africa. Men are therefore quite a difficult group to target for program intervention because they are generally not easy to meet at home.

Studies continue to show that existing strategies to save mothers' lives had been less successful than the child survival program in Nigeria despite the interventions. (Hollerbach etal.)Annually, as a result of pregnancy related complications, during pregnancy, childbirth or the post natal period about 536,000 women and girls die. Developing countries account for almost all of these deaths (99 percent) (Orji et al., 2007). According to the World Health Organization (who) report of 2008, about 358,000 maternal mortality occur in the world annually majority of which occur in sub-Saharan Africa and Southern Asia. Together, subSaharan Africa and southern Asia account for 85 per cent of all maternal deaths. This may be due to less emphasis placed on the adverse maternal outcomes due to social factors surrounding decision making at home in obstetric care (Bang et al. 2007).

In Nigeria many pregnant women are dying not because of pregnancy as a biological function, but because of the neglect they suffer in the management of the event particularly from home. These women have to take permission from their husbands before seeking care in some part of the country, their husband may not be available even in emergencies; having to do strenuous work during pregnancy; having to obey some family or cultural norms/taboos like restriction of pregnant women from eating certain foods even when these are dangerous to their health in pregnancy (Moses et al, 2007). Women in Sub-Saharan Africa are in a disadvantaged position in terms of decision making at home and they are not in control of their sexuality (Ojofehintimi et al, 2007). From research evidences, women have little or no control whatsoever over their health (Murphy et al, 2005). According to Orji, (2007) and Adegbenro (2007) Safe Motherhood Initiative has not been successful in reducing maternal mortality in Nigeria probably because interventions are centered around the women who are rather silenced or passive in taking decisions in relations to reproductive health issues in the average African family setting.

In family setting men play key role, socially and economically- he is a husband, then a father- in the formation of the family, in child education and also required to be supportive of the decisions and needs concerning the reproductive health of his wife. According to Arrows for change publication of 1996, it is evidence that not only couples, but also men and women of extended families participate in fertility issues and in decision-making regarding the use of family planning.

Following the International Conference on Population and Development (ICPD) held in Cairo in 1994, and the Fourth World Conference on Women (FWCW) in Beijing in 1995, globally, there has been an increased recognition of the need for men to take more responsibility in reproductive health matters by taking a more active role in planning pregnancy, seeking healthcare in case of adverse pregnancy outcomes and in preventing sexually transmitted Infections (STI.s), Reproductive tract infection (RTI), HIV/AIDS.

But recently males have been receiving attention as important candidates for reproductive health sciences because of their own health need and also as their sexual behaviors affect the reproductive health of their female partners. In the different subculture and social strata, the role men play as partners has different connotations and can vary widely. This is partly because men and women can be involved sexually without actually being married and can also have multiple sexual partners before marriage, within marriage, or outside marriage. While the main burden of reproductive ill-health falls on women, men may also suffer from reproductive ill health, particularly from STDs and HIV/AID, strategies to improve reproductive health must also take into account the concerns, needs, roles and responsibilities of males. 
In the past, men were not interested in "taking responsibility" for their fertility was a popular belief. Although this was certainly never true of all men, but a significant percentage of men in previous decades were taking responsibility (Griffin \& Ringheim, 1999; Heinemann et al., 2005). In a 17-country analysis of data collected during the 1990s, men's views on family size were closer to those of women than many in the reproductive health field believed (United Nations Population Division, 2005; United Nations Population Fund, 2004).

\subsection{Statement of problem}

Women bear many health burdens, such as child-bearing, fertility planning and as contraceptive side-effects associated with it, and recourse to abortion as a consequence of non-use of contraceptives or failure of family planning method. Therefore, married women of reproductive age (MWRA) have been the primary focus of reproductive health research and programme interventions. Formerly, programmes had focused on demographic and targetoriented objectives with very little emphasis on quality issues. Programmes in the past have also failed to address the relations among men and women and their responsibilities (Kuala 1996). Therefore, the importance of man in reproductive health and their responsibilities as decision makers in the process of reproduction have neither received an adequate attention nor have been investigated extensively. A man's reproductive life-span is not as clearly defined as that of a woman, may be a contributory factor.

The past programmes laid heavy emphasis on Family planning methods, the use of male, such as condom, Vasectomy, and withdrawal, has been considered as an indicator to describe "male involvement", and "male participation" in Family planning. ICPD and FWCW mandated that men's constructive roles be made part of the broader reproductive health agenda (Wegner et al 2002).

Despite academic debate on these terms, male responsibility in reproductive health has been identified as a prominent area of research and program intervention.

Men's 'reproductive responsibilities' are a stronger term which implies that men are obliged to carry out certain activities and can therefore be held accountable for their actions. To clarify, the ICPD program of Action notes, "Special efforts should be made to emphasize men's shared responsibility and enhance their involvement in responsible parenthood actively, sexual and reproductive behavior, including family planning; prenatal, maternal post-natal and child health; prevention of STIs, including HIV; and prevention of unwanted and high risk pregnancies (Green et al 2005). Such a conceptualization has broadened the role of men in reproductive health care well beyond their participation in fertility control.

With all these efforts there is still poor men's participation in maternal care service. Therefore, this study is specifically targeted at investigating why the low level of participation and enumerate measures to increase men's involvement in maternal care services.

\subsection{Justification of the study}

A key factor in the adoption and sustained safe motherhood in Nigeria is Male involvement in reproductive health where men often dominate decision (Feyisetan, 2000; Orji, 2003).In rural Nigerian communities very few studies have targeted men roles and barriers to fulfilling these roles in safe motherhood (Ogunyigbe, 2002; Feyisetan, 2000). This study is therefore designed to critically examine the role of men in safe motherhood health services in Ilesa east local government, Osun state, south west, Nigeria. This will cover pre-natal, intra-natal and post-natal care.

Reproductive health including family planning has long been viewed as solely a woman's issue, and reproductive programmes have largely focused exclusively on women. In most places around the world, whether in developing or developed countries, men are fairly involved in their partners' health care during pregnancy (Drennan, 1998).

Findings of this study will be useful for health practitioners in the areas of building knowledge as to what will constitute barriers to male involvement in maternal care services 
and see that actions are taken to remove these barriers. It will also be useful for policy makers in government to consider changes in law and policy to ensure men's involvement in maternal care services. The findings of this study is hoped to be useful for curriculum planners in education sectors to strengthen male responsibilities in family life in the education of children from the earliest ages. It will enlighten the program planners on typical roles men play in maternal care services.

\subsection{Objectives of the study}

1. To investigate the view of community members about men involvement in maternity care services.

2. To assess the level of men's involvement in maternity care services in Ilesa east local government.

3. To determine the predictors of male involvement in maternal health services

4. To identify barriers to male involvement in reproductive health services.

\section{Literature review}

\subsection{Overview of maternity care}

Several works have been carried out on maternity care. Maternity care involves care given to women from the time of pregnancy, through delivery and after delivery. (Lucas and Gilles 2003).

It is the yearning of the reproductive health workers that a woman must pass through the motherhood period safely

In the last 20 years, the issue of safe motherhood has evolved from a neglected issue to an essential and integrated element of the women's health agenda. The event that set this change in motion was a landmark worldwide movement launched in 1987 at the global Safe Motherhood Conference in Nairobi, Kenya, the Initiative sought to address the near-silent tragedy of women dying during pregnancy and childbirth ((IAG) for Safe Motherhood, 2007). It issued an international call to action to cut maternal mortality in half by the year 2000((IAG) for Safe Motherhood, 2007).Largely as a result of the initiative and the political momentum it generated, reproductive health became a central component of program and policies focusing on women's health and rights ((IAG) for Safe Motherhood, 2007). At the International Conference on Population and Development (ICPD) in 1994, maternal mortality was found to be a core component of women's sexual and reproductive health. Health problems among pregnant women are preventable, detectable and treatable through monitoring and visits with trained health workers before birth. To achieve this, the UN Children's Fund (UNICEF) and the World Health Organization (WHO) recommend a minimum of four antenatal visits. These visits will enable them to receive important services, such as tetanus toxoid, screening and treatment for infections, and have access to potentially life-saving information to recognize warning signs during pregnancy.

There is significant increase since the $1990 \mathrm{~s}$, the number of pregnant women in the developing world who had at least one antenatal care visit from around 64 per cent to 79 per cent. Substantially lower proportion of pregnant women followed the recommended four visits by WHO and UNICEF. The number of women who receive four or more antenatal visits is still less than 50 per cent in sub-Saharan Africa and Southern Asia, where the majority of maternal mortality occur. Over the last decade these figures have changed a little, indicating that maternal health and the provision of reproductive health services in those regions have scarcely advanced. (MDG report 2009)

Male involvement in sexual and reproductive health has been recognized as an integral aspect of reproductive health especially in areas where men dominate most of decisions (Feyisetan, 2000; Orji, 2003). At the Millennium Development Goal (MDG) Summit in 2000, reproductive health of women was situated within the broader context of poverty reduction efforts and overall development efforts, and with MDG 5, maternal health was recognized as a key development goal((IAG) for Safe Motherhood, 2007). 
In 1994 the International Conference on Population and Development (ICPD) increases awareness that more actions is required to achieve improvements in reproductive health outcomes generally and maternal health in particular, and the communities should be involved in the process and encourage men's active participation(Jacobstein, 2005).

According to Lucas and Gilles, 2003, the seven point agenda for Safe Motherhood are:

Information; Expand and strengthen the information base about reproductive health. This can be achieved through accurate publicity and enlightenment of both male and female, young and old on reproductive health.

- Advocacy: Disseminate relevant information about reproductive health to those who need to take action and ensure prompt action are taken in matters that can affect the reproductive health of individuals in the society.

- Education: Expand educational opportunities for girls and promote family life education for the general population. This will afford every female the opportunity to know when, where and what to seek health care for.

- Women's status: Improve the social, economic and legal status of women to liberate them from being view as second class citzen as it is found in some society.

- Family Planning: Encourage women to regulate their fertility and provide access to family planning services. This will also promote the wellbeing of the women as this will give enough time to recover from stress undergone during pregnancy, delivery and child nursing.

- Health care: Ensure that pregnant woman receive adequate care during pregnancy and childbirth by making the services available, affordable and accessible.

- Research: Promote research aimed at obtaining a clearer definition of maternal health, the determinants of morbidity and mortality including operational factors, as well as the development of new technologies.

The essential services for Safe Motherhood according to Lucas and Gilles, 2003 include:

Community education on reproductive health; prenatal care and counseling, including promotion of maternal nutrition; skilled assistance during childbirth; care for obstetric complications, including emergencies; postpartum care; management of abortion complications, post abortion care and, where abortion is not against the law, safe services for the termination of pregnancy; family planning counseling, information and services; reproductive health education and services for adolescents.

Male involvement in maternity care is essential to achieve the purpose of the services.

Involvement of male in sexual and reproductive health has become a topical issue since the concept of reproductive health and rights was adopted at the ICPD in 1994 ((IAG) for Safe Motherhood, 2007). The implications of this initiative are deeply rooted in the way each society defines gender roles and responsibilities, the progress in the involvement of men in maternity care specifically, i.e. in matters directly related to ensuring well-being and survival of mothers during pregnancy, childbirth, and after childbirth might take more time (Bongaarts et al, 2004). According to Adamchak and Chad, 2004, majority of men in most societies traditionally consider this area as the responsibilty of women and still shrouded in mystery. Now that the aim is to promote mutual supportive male-female relationships during this critical period in women's life, this subject could be internalized more rapidly through relevant educational opportunities offered to young people in schools and other social settings.(Raimi et al, 2007).

\subsection{Influence of gender roles on reproductive behavior}

Gender has a powerful influence on reproductive decision-making and behavior (Blanc et al 2006; Mccauley et al, 2004). In many developing countries men are the primary decision makers about sexual activity, fertility, and contraceptive use. Men are often called "gatekeepers" because of the many powerful roles they play in society- as husbands, fathers, uncles, religious leaders, policy-makers, and local and national leaders (Jezowski et al, 2004; Green et al, 2005). In their different roles men can control access to health information and 
services and finances and related resources such as, transportation (Roberts et al, 2007; Cohen et al 2006; Robey et al, 2008).

Little is known about the dynamics of couples' sexual and reproductive decision-making or about how gender roles affect these decisions. Such decisions can include practicing family planning, choosing when and how to have sexual relations, engaging in extramarital sex, using condoms to prevent STDs, breastfeeding, and seeking prenatal care (Bertrand et al, 2007; Blanc et 2006; Mcdonald et al, 2005).

Of the many factors that influence couples and affect their reproductive decisions, gender is just one. Education level, family pressures, social expectations, socioeconomic status, exposure to mass media, personal experience, expectations for the future, and religion also influence such decisions (Beckman, 2003; Hull et al, 2003). Consequently, no two couples' "decision-making environments" are identical (Hull et al, 2003).Suggestion has been made by some researcher that personal reproductive decisions result from many smaller, incremental decisions (Binyange et al, 2003; Mumford et al, 2003; Wilkinson et al, 2002). Others suggest that social and cultural norms and expectations often prevail over individual preferences on fertility decisions (Hull et al, 2003). In some traditional societies many couples say that the number of children they expect to have is not up to them at all, but rather up to God or to fate.

Husbands dominate reproductive decision-making, choice of contraceptive use, family size, birth spacing, or extramarital sexual partners in some developing countries (Ezeh et al, 2003; Fatima et al, 2001; Kulu et al, 2000,).

Over 3,000 urban Nigerian couples study it was found that, while men do not dominate decision-making, they still exercise more power than women do. Men and women were asked who decides such matters as family size, when to have sex, and how long periods of sexual abstinence should last. Close to $60 \%$ of men said that they decide, and $40 \%$ to $50 \%$ of women agreed that men decide (Isiugo et al, 2004). In South India a study of the fertility decisions made by five generations family also found that the men tended to control contraceptive use and made fertility decisions. The men in the older generations chose to limit their own fertility by getting vasectomies, usually without telling their wives. The men said that they were motivated to limit the number of children as a result of economic pressures.

A survey of all five generations in this family revealed that more than half of the men thought the decision-making was mutual, but only $38 \%$ of their wives saw it that way (Karra et al, 2007).

Reproductive decision-making under men's control may be weakening, particularly among younger generations and in certain cultures. As social, economic, and educational opportunities for women increase in many societies, traditional gender roles are starting to change. As a result of this, power is being redistributed between men and women (Grady et al, 2006). Result from several countries demonstrates that, increasingly, reproductive decisions are being made jointly by couples, not by men alone (Grady et al, 2006; Ogawa et al, 2003; Renne et al, 2003 ). However, the roles of men in reproductive health especially the husbands cannot be overemphasized.

\subsection{Expected mens' roles in reproductive health}

Men should help protect the lives and health of women and also attend to the health of their children. According to WHO about 342,900 women die each year from complications of pregnancy, childbirth, and unsafe abortion, about one death every minute (WHO, 2008). Majority of these deaths could be prevented (Koblinsky, 2003; Campbell, 2004).

Pregnancy-related complications is responsible for one-quarter to half of deaths among women of reproductive age in developing countries (Fortney et al, 2005; Royston et al, 2008). In some countries pregnancy-related complications are the leading cause of death of reproductive-age women (Fortney et al, 2005; Royston et al, 2008). Thousands of women in developing countries suffer serious illnesses and disabilities, including chronic pelvic pain, pelvic inflammatory disease, incontinence, and infertility, caused by pregnancy or its complications (Smith et al, 2006). 
WHO defines maternal mortality as a death occurring within 42 days after pregnancy, irrespective of the duration or the site of the pregnancy, from any cause related to or aggravated by the pregnancy or its management (WHO, 2001). The following are five direct causes-hemorrhage, sepsis, pregnancy-induced hypertension, obstructed labor, and complications of unsafe abortion and these account for more than $80 \%$ of maternal mortality (WHO, 2001).

Maternity care involves ensuring good health for women and their babies during pregnancy, delivery, and in the postpartum period. Men should play many key roles during women's pregnancy, child's delivery and after post delivery. Their decisions and actions often make the difference between illness and health, life and death (Sherpa et al, 2004; Thaddeus et al, 2003).

\subsubsection{Planning their families}

Men can take the first step to ensure good health for their spouses by planning their families (Armstrong, 2004). Limiting births and spacing them at least two years apart are good for maternal and child health. Every pregnancy carries potential health risks for women, even for women who appear healthy and at low risk (Armstrong, 2004; Johnston, 2008; Sherpa et al 2004). Unwanted pregnancies are particularly likely to carry more risky because they are more likely to result in abortion. These unsafe abortion complications cause 50,000 to 100,000 deaths each year (Hengen, 2008, WHO, 2001). There can be reduction if men can encourage their spouse and cooperate with them in planning their family.

\subsubsection{Supporting contraceptive use}

It is good for men to accompany their partners to meet with a family planning provider or health worker. Together, they can learn about the available contraceptive methods and choose the one that best meets their needs. The husband can help his partner use modern methods correctly (for example, he can help her remember her next check- up in IUCD), he can take up a male method himself, or both can agree to practice periodic abstinence. They can encourage their partners to seek help from a family planning provider if side effects occur. They can also agree to change to another method if one method proves unsatisfactory.

\subsubsection{Helping pregnant women stay healthy}

The man can make sure that his partner gets proper antenatal care when she becomes pregnant, this may entail providing transportation or/ and funds to pay for her visits. He can also accompany her on the antenatal visits, where he can learn about the symptoms of pregnancy complications.

Good nutrition and plenty of rest also are important during pregnancy. Men can encourage women have safe pregnancies and healthy babies by ensuring that they receive nutritious food, especially food rich in iron and fortified with vitamin A (Sharma et al, 2002; Sherpa et al, 2004; UNICEF, 2007). Anemia, is not a direct cause of maternal deaths, but a factor in almost all such deaths. An anemic woman is five times more likely to die of pregnancyrelated causes than a woman who is not anemic (Viteri, 2002).

Vitamin A is important to the health of both the mother and the fetus (Sharma et al, 2004). Pregnant women need to have enough vitamin A both to support the healthy development of their baby and to protect their own health, particularly their eyesight and immune system. Night blindness among pregnant women is a symptom of vitamin A deficiency. Antenatal vitamin A supplements, often provided in pill form, can greatly reduce maternal and child deaths (UNICEF, 2007).

During pregnancy there are a number of activities having implications on the health of women. Examples are difficult tasks that include carrying heavy load, bending down lot, pounding yam or doing any other hard tasks. To enhance the health of pregnant women they must take proper nutrition including taking a lot of fruits. 


\subsubsection{Arranging for skilled care during delivery}

Majority of women deliver their babies without skilled assistance, helped only by untrained traditional birth attendants or family members in developing countries.(Maswoodur 2010). A trained midwife present during childbirth can mean the difference between life and death. Husbands can help by arranging for a trained attendant/midwife to be available for the delivery and by funding the services. They also can arrange ahead of time for transportation and can buy necessary supplies.

\subsubsection{Avoiding delays in seeking care}

When complications of pregnancy occur delay often contributes to maternal deaths (Thaddeus, et al. 2004). Three types of delay put mothers' health at risk delay in deciding to seek care; delay in getting to a health care facility; and delay in receiving adequate care at the facility. Husbands and other family members play crucial roles in ensuring prompt action (Buckley, 2007; Maine, 2004). In most cases men are often the ones who decide when a woman's condition is serious enough to seek medical care. They also decide how a woman will be transported to the health facility. They can avoid delays by learning the symptoms of imminent delivery and of delivery complications.

\subsubsection{Helping after the baby is born}

Most maternal deaths occur within three days after delivery, due to infection or hemorrhage (Roudi, et al. 2006). New research suggests that men can learn about potential postpartum complications and be ready to seek help if they occur. They also can make sure that postpartum women get good nutrition while they are breastfeeding. There is need for extra vitamin A to ensure that they pass enough of the vitamin on to their babies.

Men can help with heavy housework during the postpartum period such as gathering wood and water and taking care of other children. They can encourage breastfeeding, which helps the uterus contract. Finally, they can begin using contraception, either a temporary method to space the next birth or possibly a vasectomy if no more children are desired (AAWH 2008; Ondimu, 2008; Sherpa, 2007).

\subsubsection{Being responsible fathers}

The roles of men as fathers and the ways in which they affect their children's health have been gaining attention (Byrne, 2008; Danforth, 2008; Edwards, 2008; Grady, 2006). They can still become more involved in helping their children's healthy development for example, ensuring that their children receive all of the needed immunizations. A study In Ghana found that the more education fathers have, the greater their role in deciding to immunize their children (Brugha et al, 2006).

Baltimore's Urban Fatherhood Program In the US, helps young men become responsible fathers by promoting positive male role models. Program staff members, many of whom were teenage fathers themselves, encourage other young men to be good fathers through support groups, counseling sessions, and life skills classes. They were also taught about fertility, reproduction, the menstrual cycle, pregnancy, and infant nutrition and care (Jones, 2006)

\subsection{Factors limiting men's involvement}

A number of programmatic and cultural factors have limited men's abilities to take an active role in maternity care services decision making: The "minimalist support" attitude should be examined in the light of the limited information that men have about the variety of pregnant women's needs and their lack of clarity about their roles and responsibilities in meeting these needs. Evidently, the degree of involvement will also vary according to the social and cultural context. Too often in the past, men were presented as an obstacle and not as part of the solution. Men play powerful - even dominant - roles in reproductive decisions. Men's participation in reproductive health is a crucial step in decreasing maternal and child mortality (Obermeryer etal, 2003; Lasee et al, 2007). 
The majority of interventions and services to promote sexual and reproductive health, including care during pregnancy and childbirth, have been exclusively focused on women (Green et al, 2003). Yet, men and women living in the same society are influenced by the same beliefs about the roles and responsibilities that are appropriate for each gender. Men are not the only ones to blame for the slow changes in gender-based imbalances. In societies where maternal mortality and severe morbidity are high, men and women face similar challenges related to the social, cultural and political complexities underlying these events, including the pressure for high fertility and lack of safety measures when obstetric complications arise. Therefore, it should be assumed that, for all that is leading to maternal survival as defined in the Mother-Baby Package, there is always a man standing by the side of every woman knocking at the "gate" before, during and after each pregnancy (WHO, 2005).

\subsubsection{Gaps in male focused health services}

Most reproductive health services are designed to meet women's or children's needs and, as a result, men often do not consider them as a source of information and services. Currently, political support for male involvement is manifested by a lack of opposition to it rather than by any specific support. Many may be inconvenient or unwelcoming to men, and providers may not have the training or skills necessary to meet men's reproductive health needs. Men also may be embarrassed about visiting a facility that primarily serves women. Men's lack of access to services has been a barrier to their involvement in safe motherhood. Men cannot share responsibility for reproductive health if services and information do not reach them. Most FP clinics cater to women, so men are uncomfortable about going to these clinics. Men must be reached in other ways. This testimony from a Kenyan man is a good illustration of that need:

"After having three children, my wife went on the pill for her contraception because we could no longer afford an accident with the natural methods we were using. Her blood pressure immediately shot up, and she was advised to discontinue. She tried other methods, but they had complications too. I felt I was unfair and it was my duty, too, to take part in family planning. One morning we went together to our local family-planning clinic. I will never forget how embarrassed I felt. There was not even a single man there, just queues of women and their babies. This was a woman's world and I felt totally lost."(Wambui, 2005). This confirms the assumption that no matter how many men want to know and participate in reproductive health, most reproductive health programs have not yet given adequate attention to serving them.

\subsection{Potential benefits of male involvement in maternity care}

Provision of reproductive health information and services to men benefits both men and women in several ways. Reproductive health programs can help men cooperate with their sexual partners to avoid unwanted pregnancies and to prevent sexually transmitted diseases. (STDs).

\subsubsection{Promotion of contraceptive use and prevention of STDs}

Men involvement in reproductive health services increases access to contraceptive methods that men can use, thereby expanding a couple's range of contraceptive options. It also improves men's support for women's use of contraception and shared reproductive decision making, and prevents STD transmission thereby preventing maternal morbidity and mortality. It is widely acknowledged that men in developing countries make most of the decisions regarding family formation (Freedman et al, 2003). Despite women's increasing influence on household decision making, their preferences regarding contraceptive choices and family size may not translate into practice unless they conform to their husbands' wishes (Morgan et al, 2005). In this context, the decision to have or not to have children is the male's(Ojofeitimi et $\mathrm{al}, 2009)$. Isiugo-Abanihe, et al(2004) noted that male dominance is particularly profound in 
matters of reproduction. They generally view reproduction as their prerogative, an issue in which the compliance of their wives is taken for granted.

Well-informed men can participate fully in reproductive health as they use a method of family planning themselves or support their partners in using a method. They can also talk with their wives and cooperate in assessing their needs and choosing a family planning method (Ogunjuyigbe et al, 2009).Except for female prostitutes, men are likely to have more sexual partners than women. They have more control over condom use and are more likely to control the frequency of sexual relations and the possibility of abstinence within a relationship (Ojofeitimi et al, 2009). One factor driving emphasis on the couple over the individual, as observed by Biddlecom and Fapohunda, has been an increasing number of studies that demonstrate the influence of a man's preferences and power on reproductive outcomes such as contraceptive use, childbearing and views about family planning (Liasu et al, 2009). Based on these studies, one could argue that reproductive health programs that attempt to reach women will have a higher probability of success if they also involve the husband or at least encourage such involvement. Therefore, an understanding of the males' influence and the role they play in decision-making on contraceptive use can throw better light on mechanisms through which fertility reduction can be achieved.

\subsubsection{Reduction of maternal mortality and morbidity}

Maternal mortality is a major public health problem in the world, and ensuring access to necessary health care including emergency obstetric services is a prerequisite for reducing maternal mortality. Men are important stakeholders in and can be possible barriers to women's health care seeking in pregnancy, delivery and post-partum period, and their involvement is essential for their health (Paullina et al, 2009).

When a mother dies, children and fathers lose their primary caregiver, communities are denied her paid and unpaid labour, and countries forego her contributions to economic and social development. A woman's death is more than a personal tragedy - it represents an enormous cost to her nation, her community and her family (Abhay, et al, 2007). Any social and economic development that has been made in her life is lost. Her family loses her love, her nurturing and her productivity inside and outside the home.

Most maternal deaths are rooted in inadequate participation of men in reproductive health (Anjana et al, 2007). Support needed by women especially during pregnancy, childbirth and after childbirth from their husband is often not given, may then result in late or no prenatal care, lack of skilled attendants at every birth, delays at home in deciding to seek emergency treatment; delay in reaching an institution that can provide emergency obstetric care; practice of unsafe sex and may finally lead to increased maternal morbidity and mortality (Friedan et al, 2005). Making motherhood safer requires men's adequate participation and support in reproductive roles.

In this scenario, good health for the mother is the watchword and preventing maternal deaths and illness is an issue for both men and women.

\section{Methodology}

\subsection{Research design}

This study utilized a descriptive, cross-sectional research design to obtain information using a self administered structured questionnaire to obtain quantitative data on men's attitude towards utilization of maternity care services by their spouses in Ilesa East Local Government.

The questionnaire was both in English and Yoruba language to ensure both literates and illiterates participate.

\subsection{Study setting}

The study was conducted in 11 wards of the Ilesa East Local Government area which is located in Osun state Nigeria, on coordinates $7^{\circ} 37^{\circ} \mathrm{N}$ (Latitude) and Longitude $4^{\circ} 43^{\circ} \mathrm{E}$. The 
Local Government Area occupies $71 \mathrm{~km}^{2}$ (27.4sqm) land space. According to National Population Commission, 2006, the 11 wards have a combined population of 106,586. It has its head-quarters and secretariat at Iyemogun in Ilesa town.

The inhabitants of this area are of multi-ethnic background with the Yorubas the dominant group while a sizeable proportion of the population consists of Igbos and Hausas. The major occupation are farming and trading. Other residents are civil servants and artisans.

\subsection{Target population}

The target population are married men who are of child bearing age in Ilesa East Local Government Area.

\subsection{Sample size}

Sample size of respondents was estimated using the Computer Programme for Epidemiologists (PEPI), version 3.01, employing the sample size formula for estimation of proportions as described by Armitage and Berry.

Sample size $(\mathrm{n})=\mathrm{P}(1-\mathrm{P}) \mathrm{Z}^{2} / \mathrm{d}^{2}$

Where $\mathrm{n}=$ minimum sample size

$\mathrm{P}=$ crude estimate of true proportion in the population. (From the Nigeria Demographic and Health Survey 2008) figures, the estimate of true proportion of mothers that receive some ante natal care $58 \%$

$\mathrm{Z}=$ standard normal variant corresponding to level of confidence at $95 \%$ and for a 2 -tailed test $Z=1.96$

$d=$ maximal allowable difference from true proportion; this was accepted at 5\% (0.05).

Sample size (n) of 375 was obtained as the minimum sample size. However, to take care of those that may be lost due to non- submission of questionnaire and to permit robust analysis, the sample size was increased to 500 .

\subsection{Sampling method}

A convenience sampling technique was used based on the major occupational groups in the community. Twelve occupational groupings were identified and a total of 42 respondents per occupational grouping were selected for interview spread over 11 wards. See appendix for list of occupational groups. The respondents were selected from their places of work based on the inclusion criteria of being married with children while those that were not married, without children and declined consent were excluded from participation.

\subsection{Instrument development}

A semi structured questionnaire was utilized for the study. It consisted of closed and open ended questions, organized into sections A to D and was translated from English to Yoruba and back translated from Yoruba to English.

\subsection{Validity}

Face Validity: The instrument was presented to the researcher's supervisor for approval regarding the suitability and appropriateness of the items.

Content validity: The supervisor assessed the content and any unclear or ambiguous questions were modified before it was administered on the target population.

\subsection{Pretest}

A pretest was conducted in Atakumosa Local Government to be able to modify and correct ambiguous questions in the questionnaire.

\subsection{Procedure for data collection}

The research instrument was an interviewer-administered questionnaire targeted to married men in the selected wards of Ilesa east Local Government, Ilesa. The researcher explained about the study men and consent obtained before the administration of the 
South American Journal of Nursing

Special Edition 2016

questionnaire. Questionnaires were administered based on language preference of the respondents.

\subsection{Ethical consideration}

Permission for study was obtained from respective community leaders.

Participants were required to give a verbal consent to participate in the study. The reluctance of the respondents to discuss potentially sensitive matters was eliminated by assuring the participants of the confidentiality of the information provided which is purely for research purpose. Also the anonymity and of the respondents were assured.

\subsection{Data analysis}

The number of questionnaires that were properly filled was analyzed using the PC, SPSS software version 16. Appropriate descriptive and inferential statistics were applied.

Discrete variables were presented using tables and charts; test of association was conducted using chi-square. P value was set at $<0.05$.

\subsection{Scoring variables}

Fourteen questions were asked on involvement of respondents in maternity care services, two marks were given for each question to those who perform the role all the time, those that choose 'sometimes' were given one mark, while that never perform the role scored zero for each question. The highest possible score was 28 and lowest was 0 . Based on the performance, those that scored 21-28 were assumed to be well involved, those that scored 1420 were said to be partially involved while those that scored below 13 were grouped into not involved.

Twenty-three questions were asked on community perception of men involvement in maternity care services. Four marks were given to those who strongly agree with stated expected role of men, three was given to those that just agree and two, one and zero for those that disagree, undecided and strongly disagree respectively. Therefore the highest possible mark was 92 . Those that scored between 0 and 46 were said to be poorly involved, those that scored between 47 and 69 were said to have fair perception, and scores from 70 to 92 were assumed to have good perception of men involvement in maternity care services.

\section{Results}

Five hundred questionnaires were administered; five hundred were received and used for analysis. The number of responses from the data was expressed in percentages against the whole number.

Table 1: Socio-demographic profile of respondents

\begin{tabular}{|c|c|c|}
\hline Variable & FREQUENCY & PERCENTAGE (\%) \\
\hline \multicolumn{3}{|c|}{ Age of respondents } \\
\hline 30 to 42 & 205 & 41.0 \\
\hline 43 to 55 & 218 & 43.6 \\
\hline 56 to 67 & 77 & 15.4 \\
\hline \multicolumn{3}{|l|}{ Ethnicity } \\
\hline Yoruba & 463 & 92.6 \\
\hline Igbo & 27 & 5.4 \\
\hline Hausa & 10 & 2.0 \\
\hline \multicolumn{3}{|l|}{ Religion } \\
\hline Christianity & 369 & 73.8 \\
\hline Islam & 131 & 26.2 \\
\hline \multicolumn{3}{|c|}{ Educational status } \\
\hline Primary & 119 & 23.8 \\
\hline Secondary & 174 & 34.8 \\
\hline
\end{tabular}




\begin{tabular}{lll}
$\begin{array}{l}\text { Tertiary } \\
\text { Number of wives }\end{array}$ & \multicolumn{2}{l}{207.4} \\
One & 323 & 64.6 \\
Two & 115 & 23.0 \\
Three & 62 & 12.4 \\
Current & number of children & \\
1 to 4 & 301 & 60.2 \\
5 to 8 & 172 & 34.4 \\
9 to 12 & 27 & 5.4 \\
Age of last child & \\
1 to 4 & 332 & 64.6 \\
5 to 9 & 88 & 17.6 \\
10 to 19 & 72 & 14.4 \\
20 and above & 8 & 1.6 \\
\hline
\end{tabular}

In table 1 above, about $85 \%$ of respondents were less than 55 years of age, majority of them (92.6)were of Yoruba ethnicity and they were predominantly Christian (74\%). About $40 \%$ of them had tertiary education with over $60 \%$ in monogamous relationship.

Majority $(60.2 \%)$ have between 1 and 4 children with $65 \%$ of respondents having a last child less than 4 years of age.

Table 2: Level of involvement of respondents in maternity care services

\begin{tabular}{lll}
\hline Level of involvement & Frequency & Percentage \\
\hline Well involved & 362 & 72.4 \\
Partially involved & 138 & 27.6 \\
Total & 500 & 100 \\
\hline
\end{tabular}

The table shows that $362(72.4 \%)$ of respondents were well involved in Maternity care services, while $138(27.6 \%)$ were partially involved; none of the respondents was not involved in maternity care services.

Table 3: Role of men in maternity care prenatal care

\begin{tabular}{|c|c|c|c|c|c|}
\hline \multirow{2}{*}{$\begin{array}{l}\text { Role of man in maternal } \\
\text { care }\end{array}$} & \multicolumn{5}{|c|}{ Level of agreement } \\
\hline & $\begin{array}{l}\text { Strongly } \\
\text { Agree (\%) }\end{array}$ & $\begin{array}{l}\text { Agree } \\
(\%)\end{array}$ & $\begin{array}{l}\text { Disagree } \\
\text { (\%) }\end{array}$ & $\begin{array}{l}\text { Strongly } \\
\text { Disagree } \\
\text { (\%) }\end{array}$ & $\begin{array}{l}\text { Undeci } \\
\text { ded }(\%)\end{array}$ \\
\hline $\begin{array}{l}\text { Ensure that the pregnant } \\
\text { mother gets proper antenatal } \\
\text { care }\end{array}$ & $457(91.4)$ & $32(6.4)$ & $1(0.2)$ & $0(0)$ & $8(1.6)$ \\
\hline $\begin{array}{l}\text { Provide transportation or } \\
\text { funds for pregnant mothers } \\
\text { antenatal visits }\end{array}$ & $378(75.6)$ & $57(11.4)$ & $59(11.8)$ & $6(1.2)$ & $0(0)$ \\
\hline $\begin{array}{l}\text { Accompany the pregnant } \\
\text { mother on the antenatal visits }\end{array}$ & $378(75.6)$ & $46(9.2)$ & $24(4.8)$ & $37(7.4)$ & $15(3,0)$ \\
\hline $\begin{array}{l}\text { Ensure that spouse receives } \\
\text { good nutrition and adequate } \\
\text { rest. }\end{array}$ & $382(76.4)$ & $115(23)$ & $3(0.6)$ & $0(0)$ & $0(0)$ \\
\hline $\begin{array}{l}\text { Taking active role in working } \\
\text { out a plan for delivery of the } \\
\text { baby }\end{array}$ & $353(70.6)$ & $34(6.8)$ & $22(4.4)$ & $23(4.6)$ & $\begin{array}{l}68 \\
(13.6)\end{array}$ \\
\hline $\begin{array}{l}\text { Ensure that spouse receives } \\
\text { appropriate immunization }\end{array}$ & $435(87.0)$ & $30(6.0)$ & $11(2.2)$ & $16(3.2)$ & $8(1.6)$ \\
\hline Ensure that spouse receives & $327(65.4)$ & $48(9.6)$ & $82(16.4)$ & $31(6.2)$ & $12(2.4)$ \\
\hline
\end{tabular}


South American Journal of Nursing

Special Edition 2016

malaria prophylaxis or

treatment

Learning the symptoms of

imminent delivery and of

$296(59.2)$

$35(7.0)$

$45(9.0)$

$71(14.2)$

53

delivery complications

From table 3 above, majority of respondents agree with the named role of men in maternity care services at the prenatal level, the highest was seen in the role "Ensure that the pregnant mother gets proper antenatal care" where 457 (91.4\%) strongly agreed and 32 (6.4\%) agreed only $1(0.2 \%)$ respondent disagree and none strongly disagree.

The lowest was seen in the question "learning the symptoms of imminent delivery and of delivery complications;" here less than $60 \%$ of respondents strongly agreed, while only $7 \%$ agreed, $9 \%$ disagreed and $14.2 \%$ strongly disagreed while 10.6 were undecided.

Table 4: Role of men in maternity care delivery

\begin{tabular}{|c|c|c|c|c|c|}
\hline \multirow{2}{*}{$\begin{array}{l}\text { Role of man in maternal } \\
\text { care }\end{array}$} & \multicolumn{5}{|c|}{ Level of agreement } \\
\hline & $\begin{array}{l}\text { Strongly } \\
\text { Agree (\%) }\end{array}$ & $\begin{array}{l}\text { Agree } \\
(\%)\end{array}$ & $\begin{array}{l}\text { Disagre } \\
\text { e (\%) }\end{array}$ & $\begin{array}{l}\text { Strongly } \\
\text { Disagree } \\
(\%)\end{array}$ & $\begin{array}{l}\text { Undeci } \\
\text { ded }(\%)\end{array}$ \\
\hline $\begin{array}{l}\text { Ensuring that delivery is } \\
\text { taken by trained attendant }\end{array}$ & $289(57.8)$ & $37(7.4)$ & $23(4.6)$ & $106(21.2)$ & $45(9.0)$ \\
\hline $\begin{array}{l}\text { Paying for the delivery } \\
\text { services }\end{array}$ & $424(84.8)$ & $47(9.4)$ & $29(5.8)$ & $0(0)$ & $0(0)$ \\
\hline $\begin{array}{l}\text { Paying for services rendered } \\
\text { during childbirth }\end{array}$ & $435(87)$ & $63(12.6)$ & $2(0.4)$ & $0(0)$ & $0(0)$ \\
\hline $\begin{array}{l}\text { Arranging ahead of time for } \\
\text { transport }\end{array}$ & $372(74.4)$ & $70(14.0)$ & $2(0.4)$ & $36(7.2)$ & $0(0)$ \\
\hline $\begin{array}{l}\text { Avoiding delays in deciding } \\
\text { and seeking health care }\end{array}$ & $372(74.4)$ & $116(23.3)$ & $10(2.0)$ & $0(0)$ & $2(0.4)$ \\
\hline $\begin{array}{l}\text { Supporting spouse } \\
\text { psychologically during labour }\end{array}$ & $424(84.8)$ & $59(11.8)$ & $17(3.4)$ & $0(0)$ & $0(0)$ \\
\hline
\end{tabular}

In table 4 over $75 \%$ strongly agreed with all the identified role of men during delivery except attendance of birth by skilled personnel where only about $60 \%$ strongly agreed.

Table 5: Role of men in maternity care (postnatal period)

\begin{tabular}{llllll}
\hline Role of man in maternal & \multicolumn{2}{l}{ Level of agreement } & & & \\
\cline { 2 - 6 } & $\begin{array}{l}\text { Strongly } \\
\text { Agree (\%) }\end{array}$ & $\begin{array}{l}\text { Agree } \\
\mathbf{( \% )}\end{array}$ & $\begin{array}{l}\text { Disagree } \\
\mathbf{( \% )}\end{array}$ & $\begin{array}{l}\text { Strongly } \\
\text { Disagree }\end{array}$ & $\begin{array}{l}\text { Undecided } \\
\mathbf{( \% )}\end{array}$ \\
& $398(79.6)$ & $26(5.2)$ & $27(5.4)$ & $33(6.6)$ & $16(3.2)$ \\
$\begin{array}{l}\text { Helping spouse with heavy } \\
\text { household work }\end{array}$ & $409(81.8)$ & $57(11.4)$ & $18(3.6)$ & $16(3.2)$ & $0(0)$ \\
$\begin{array}{l}\text { Ensuring that child receives all } \\
\text { needed immunizations }\end{array}$ & & & & & \\
\hline
\end{tabular}

From table 5 about $85 \%$ of respondents agreed with helping spouse with heavy household works especially during postnatal period while, $12 \%$ did not support the role and $3.2 \%$ of the respondents were undecided.

Majority (93.2\%) of the respondents support ensuring that their children receive all the needed immunization and $6.8 \%$ did not support it as the role of men.

Table 6: Role of men in maternity care (family planning)

\begin{tabular}{llllll}
\hline Role of man in maternal & \multicolumn{4}{l}{ Level of agreement } & \\
\cline { 2 - 6 } care & Strongly & Agree & Disagree & Strongly & Undecided \\
& Agree (\%) & $\mathbf{( \% )}$ & $\mathbf{( \% )}$ & Disagree & $(\%)$
\end{tabular}


Planning your family by

limiting births and spacing

them

Preventing unwanted

pregnancy by using FP

method

Join partner to meet with FP

counselor

Join partner to learn and

choose FP method

Helping your partner to use

modern FP methods correctly

Cooperating with partner to

practice periodic abstinence

Seeking help from health care

providers if side effects occur

\begin{tabular}{lllll}
\hline $324(64.8)$ & $26(5.2)$ & $45(9.0)$ & $\begin{array}{l}\mathbf{( \% )} \\
86(17.2)\end{array}$ & $19(3.8)$ \\
$297(59.4)$ & $47(9.4)$ & $35(7.0)$ & $106(21.2)$ & $15(3.0)$ \\
$384(76.8)$ & $20(4)$ & $28(5.6)$ & $44(8.8)$ & $24(4.8)$ \\
$373(74.6)$ & $28(5.6)$ & $44(8.8)$ & $30(6.0)$ & $25(5.0)$ \\
$375(75)$ & $56(11.2)$ & $19(3.8)$ & $22(4.4)$ & $28(5.6)$ \\
$300(60)$ & $51(10.2)$ & $38(7.6)$ & $54(10.8)$ & $57(11.4)$ \\
$350(70)$ & $53(10.6)$ & $19(3.8)$ & $47(9.4)$ & $31(6.2)$ \\
\hline
\end{tabular}

From table 6a large number of respondents supported family planning as role of men in maternity care in a supportive role and not as active participant in the use of FP methods as only $60 \%$ strongly agreed to cooperate with spouse in practicing periodic abstinence and preventing pregnancy by using FP methods. .

Table 7: Community perception of men involvement in maternity care services

\begin{tabular}{lll}
\hline PERCEPTION & FREQUENCY & PERCENTAGE (\%) \\
\hline Good perception & 359 & 71.8 \\
Fair perception & 131 & 26.2 \\
Poor perception & 10 & 2.0 \\
Total & 500 & 100 \\
\hline
\end{tabular}

In table 7 majority (71.8\%) of the population had good perception of men's involvement in maternity care services, $26.2 \%$ had fair perception and only $2 \%$ of the population had poor perception of men involvement in maternity care services.

Table 8: Barriers to male involvement in maternity care.

\begin{tabular}{|c|c|c|c|c|c|}
\hline \multirow[t]{2}{*}{ Barriers } & \multicolumn{5}{|c|}{ Level of agreement with barriers } \\
\hline & $\begin{array}{l}\text { Strongly } \\
\text { Agree (\%) }\end{array}$ & $\begin{array}{l}\text { Agree } \\
(\%)\end{array}$ & $\begin{array}{l}\text { Disagree } \\
(\%)\end{array}$ & $\begin{array}{l}\text { Strongly } \\
\text { Disagree } \\
\text { (\%) }\end{array}$ & $\begin{array}{l}\text { Undecided } \\
(\%)\end{array}$ \\
\hline $\begin{array}{l}\text { Lack of access to accurate } \\
\text { information about safe motherhood }\end{array}$ & $487(97.4)$ & $9(1.8)$ & $1(0.2)$ & $2(0.4)$ & $1(0.2)$ \\
\hline $\begin{array}{l}\text { Services exclusively focused on } \\
\text { women }\end{array}$ & $494(98.8)$ & $5(1.0)$ & $0(0)$ & $1(0.2)$ & $0(0)$ \\
\hline $\begin{array}{l}\text { Lack of appropriate policy that } \\
\text { support men's role }\end{array}$ & $496(99.2)$ & $4(0.8)$ & $0(0)$ & $0(0)$ & $0(0)$ \\
\hline Dominance of female care providers & $493(98.6)$ & $6(1.2)$ & $0(0)$ & $0(0)$ & $1(0.2)$ \\
\hline $\begin{array}{l}\text { Unwelcoming approach of care } \\
\text { providers to men }\end{array}$ & $488(97.6)$ & $9(1.8)$ & $1(0.2)$ & $1(0.2)$ & $1(0.2)$ \\
\hline $\begin{array}{l}\text { Hospital policy that does not } \\
\text { encourage male participation }\end{array}$ & $497(99.4)$ & $2(0.4)$ & $0(0)$ & $1(0.2)$ & $0(0)$ \\
\hline Manpower and space problem & $492(98.4)$ & $5(1)$ & $0(0)$ & $290.4)$ & $1(0.2)$ \\
\hline Societal disapproval of open & $495(99)$ & $4(0.8)$ & $0(0)$ & $0(0)$ & $1(0.2)$ \\
\hline
\end{tabular}


South American Journal of Nursing

Special Edition 2016

discussion of sexual matters

Religion's disapproval of open

$497(99.4) \quad 2(0.4) \quad 0(0)$

$1(0.2)$

$0(0)$

discussion of sexual matters

Job responsibilities

$496(99.2) \quad 3(0.6) \quad 0(0)$

$1(0.2) \quad 0(0)$

From table 8 majority of the respondents supported factors identified as barriers to male involvement in maternity care services.

Financial constraint, Poor health of husband and Ignorance were also identified by respondents as factors hindering them from participation in maternal care.

Table 9: Assessment of the association between age and male involvement in maternity care services

\begin{tabular}{lllll}
\hline Age & \multicolumn{4}{l}{ Level of involvement } \\
\cline { 2 - 5 } & Partial (\%) & Well (\%) & Total & $\chi^{\mathbf{2}=\mathbf{3 . 3 4}}$ \\
$30-42$ & $65(31.7)$ & $140(68.3)$ & $205(41.0)$ & $\mathbf{p}=\mathbf{0 . 5 4}$ \\
$43-55$ & $53(24.3)$ & $165(75.7)$ & $218(43.6)$ & \\
$56-67$ & $20(26.0)$ & $57(74.0)$ & $77(15.4)$ & \\
Total & $138(27.6)$ & $362(72.4)$ & $500(100)$ & \\
\hline
\end{tabular}

In table $9,74 \%$ of respondents within age 56 to 67 years were well involved in maternity care in comparison with $75.7 \%$ among those of age 43 to 55 years and those of age range 30 to 42 years. There was no significant relationship between age and level of involvement.

Table 10: Assessment of the association between religion and male involvement in maternity care services

\begin{tabular}{lllll}
\hline Religion & \multicolumn{4}{l}{ Level of involvement } \\
\cline { 2 - 5 } & \multicolumn{1}{l}{ Partial (\%) } & Well (\%) & Total & $\chi^{\mathbf{2}=\mathbf{1 . 3 8}}$ \\
Christianity & $107(29.0)$ & $262(71.0)$ & $369(73.8)$ & $\mathbf{p}=\mathbf{0 . 2 4}$ \\
Islam & $31(23.7)$ & $100(76.3)$ & $131(26.2)$ & \\
Total & $138(27.6)$ & $362(72.4)$ & $500(100)$ & \\
\hline
\end{tabular}

From the above table, religion was not significantly associated $(p=0.24)$ with level of involvement of men, over $70 \%$ of respondents from both religions were well involved.

Table 11: Assessment of the association between ethnicity and male involvement in maternity care services

\begin{tabular}{lllll}
\hline Ethnicity & \multicolumn{4}{l}{ Level of involvement } \\
\cline { 2 - 5 } & Partial (\%) & Well (\%) & Total & $\chi^{\mathbf{2}=\mathbf{1 . 5 0}}$ \\
Yoruba & $131(28.3)$ & $332(71.7)$ & $463(92.6)$ & $\mathbf{p}=\mathbf{0 . 2 6}$ \\
Others & $7(18.9)$ & $30(80.1)$ & $37(7.4)$ & \\
Total & $138(27.6)$ & $362(72.4)$ & $500(100)$ & \\
\hline
\end{tabular}

From table 11 above, there was no significant association $(\mathrm{p}=0.10)$ between ethnicity and male involvement as $71.7 \%$ of respondents who are of Yoruba ethnic group were well involved in maternity care compared to $80.19 \%$ of the other tribes. .

Table 12: Assessment of the association between educational status and male involvement in maternity care services

\begin{tabular}{lllll}
\hline Educational & \multicolumn{4}{l}{ Level of involvement } \\
status & Partial (\%) & Well (\%) & Total & $\chi^{2}=6.46$
\end{tabular}




\begin{tabular}{llll} 
Primary & $33(28)$ & $86(72)$ & $119(24)$ \\
Secondary & $59(34)$ & $115(66)$ & $174(35)$ \\
Tertiary & $46(22)$ & $161(78)$ & $207(41)$ \\
Total & $138(27.6)$ & $362(72.4)$ & $500(100)$ \\
\hline
\end{tabular}

$\mathrm{p}=\mathbf{0 . 0 4}$

Level of education was significantly associated (0.04) with male involvement with $78 \%$ of respondents with tertiary education being well involved compared to $66 \%$ of those who had secondary education and $72 \%$ with primary school education.

Table 13: Assessment of the association between number of wives and male involvement in maternity care services

\begin{tabular}{lllll}
\hline \multirow{2}{*}{$\begin{array}{l}\text { Number of } \\
\text { wives }\end{array}$} & \multicolumn{4}{l}{ Level of involvement } \\
\cline { 2 - 5 } $\mathbf{1}$ & Partial (\%) & Well (\%) & Total & $\chi^{\mathbf{2}=\mathbf{1 3 . 9 2}}$ \\
$\mathbf{2}$ & $107(33.1)$ & $216(66.9)$ & $323(100)$ & $\mathbf{p}<\mathbf{0 . 0 0 1}$ \\
Total & $31(17.5)$ & $145(82.5)$ & $177(100)$ & \\
\hline
\end{tabular}

In table 13 above, there was a significant relationship $(p<0.001)$ between number of wives and level of involvement with $66.9 \%$ of those that had one wife among the respondents well involved in maternity care, while $82.5 \%$ of respondents that had more than one wife were well involved in maternity care.

\section{Discussion of findings}

The demographic data shows that majority of the respondents were within the age range of $30-55$ years and were Christians of Yoruba ethnicity who had tertiary school education. Most of the respondents had only one wife each and the number of children for majority varied from age 1-4. Also, the ages of the last child for majority were between 1-7 years.

Determining the level of involvement of respondents in maternity care services findings of this research study show that majority of the respondents were well involved, while below average were partially involved and none was not involved in maternity care services. This affirms the work of Jezowski et al, 2004 and Green et al, 2005 which refer to men as "gatekeepers" because of the role they play in the family. Also, majority of respondents agree with the named role of men in maternity care services at the prenatal delivery postnatal and Family planning levels in keeping with the Arrows for change publication of 1996, which stated that man plays a key role in decisions and needs pertaining to the health of his wife. It also pointed out that not only women participate in decision making of contraceptive use as in this study majority of the men strongly with use of contraception by women and not by them directly. This finding is consistent with the result of a 17-country analysis study conducted during the 1990s, which showed that men's views on family size were closer to those of women than many in the family planning field hitherto believed (United Nations Population Division, 2005; United Nations Population Fund, 2004).

In an attempt to identify the community members' perception of men involvement in maternity care services, the study revealed that well above average proportion of the respondents has good perception while below average of the population had poor perception about men involvement in maternity care services. This is in support of what Feyisetan(2000) and Orji(2007) said that male involvement in sexual and reproductive health has been recognized as an integral aspect of reproductive health.

From the findings, majority of the respondents supported factors identified by researcher as barriers to male involvement in maternity care services and were able to name other factors that they consider to be hindering them from being well involved in maternity care services. This is similar to the findings of New York Population Council and that of Arrows for Change that said Women bear many health burdens, such as child-bearing, fertility regulation and 
associated contraceptive side-effects, and recourse to abortion as a consequence of non-use of contraceptives or method failure. It is also in consistent with other studies conducted in Uganda, Bangladesh and Tanzania (Raymond Tweheyo et al. 2010) Thus, married women of reproductive age (MWRA) have been the primary focus of reproductive health research and programme interventions. In the past, programmes had focused on demographic and targetoriented objectives with very little emphasis on quality issues. Programmes have also failed to address the relations among men and women and their responsibilities. Therefore, the role of man in reproductive health and their responsibilities as important decision makers in the process of reproduction have neither received an adequate attention nor have been investigated extensively. This is primarily because a man's reproductive life-span is not as clearly defined as that of a woman.

Because of heavy emphasis of the past programmes on family planning, the use of male methods, such as condom, Vasectomy, and withdrawal, has long been considered as an indicator to describe "male involvement", and "male participation" in Family planning.

The study found a significant relationship between educational status and level of involvement of men in maternity care services.

Another significant finding of the study is the discovery that there is no relationship between each of age, religion and ethnicity and level of involvement of men in maternal care.. Also, there is relationship between number of wives and the level of involvement in maternal care among men. This is in keeping with the assertion by Griffin \& Ringheim as well as that of Heinemann which states that for many decades, when the level of education was still very low relative to now, the popular belief was that men were not interested in taking responsibility in reproductive matters but now it can be seen that with education more men are involved in maternal health care.

\subsection{Summary}

Among the community members, over half have a right perception about men involvement in maternity care services. Therefore they consider it not bad for men to be involved in their wives' utilization of maternity care services.

The level of involvement of men in maternity care services can be improved upon; though many of the men in the community have good knowledge about maternity care services, there are still some men in the community who are not well involved.

Some factors such as level of education and number of wives are predictors of male involvement in maternal health services

The respondents strongly agreed that there were barriers to male involvement in maternal care services.

\subsection{Conclusion}

In synopsis, the result of the study shows that males in the study community have a good understanding of their roles in maternal health services and they are willing to be involved if their spouses are ready to make use of them. However, their involvement is limited due to several barriers within the health care setting which make male participation difficult.

\subsection{Recommendations}

Based on the findings of this study, the following recommendations are made in order to improve on the involvement of males in utilization of maternal health services by their spouses.

1. Teachings on involvement of men in maternity care should start earlier before marriage at home, schools religious gatherings and other social sectors.

2. Policies should be put in place to remove or reduce barriers to male involvement in maternal health care. 
3. A lasting basis should be created for the development of the knowledge of the community about the maternal health such as timely seminar, health talks at different working places and social gatherings.

4. Health practitioners should recognize and encourage involvement of men in maternity care services.

5. Policies should be made to encourage men to provide adequate support to their spouses especially during the reproductive years.

6. Paternity leave should be advocated for as is found in some countries.

7. A wider research study on this topic should be carried out covering a wider range of population so that the findings of this study can be generalized.

8. Marriage should be seen as a responsibility therefore, men should not marry more than the number of wives they can care for.

\subsection{Suggestion for further studies}

A similar research study should be carried out using community members of other Local Governments in and outside Osun State to examine the extent by which the findings of the study can be generalized.

\section{References}

[1.] Adewuyi A.A. (2003) Pregnancy Care: Understanding male involvement in maternal emergencies. Centre for Research, evaluation, resources and development, Ede, Osun State, Nigeria,

[2.] Akafuati et.al. (June 2008) Attitudes toward and use of knowledge about family planning among Ghanian men. Inetrnational journal of men's health online library.

[3.] Armstrong, B. (May 2004.) (Columbia School of Public Health) [Cyclical level of interest in men's participation in reproductive health] Personal communication

[4.] Bang et.al. (2007) Effect of Home Based Neo natal care and management of sepsis on neonatal mortality: field trial in rural India,

[5.] Bankole A and Singh S. (2008)couples' fertility and contraceptive decision-making in developing countries: hearing the man's voice. International family planning perspectives; 24 (1): 15-24

[6.] Barbara F et al (2002) Bailliere's Nurses' Dictionary, Twenty-second edition. Bailliere Tindall London.

[7.] BBC English Dictionary $1^{\text {st }}$ edition 1992, HarperCollins Publishers 77-85 Fulham Palace Road Hammersmith London W6 8 JB.

[8.] Beckman, L. , (2003). Communication, power and the influence of social networks in couple decisions on fertility. In: Bulatao, R.A., Lee, R.D., Hollerbach, P.E., and Bongaarts, J., eds. Determinants of fertility in developing countries. Vol. 2: Fertility regulation and institutional influences. New York, Academic Pressp. 415-443

[9.] Bertrand et al (2007) The male versus female perspective on family planning: Kinshasa, Zaire. Journal of Biosocial Science 28(1): 37-55.

[10.] Binyange et al. (2003) Vasectomy decision-making in Rwanda. New York, AVSC International, $44 \mathrm{p}$.

[11.] Blanc et al,(2006). Negotiating reproductive outcomes in Uganda. Calverton, Maryland, Macro International, $214 \mathrm{p}$.

[12.] Brugha, et al. (Aug. 2006). An investigation of the role of fathers in immunization uptake. International Journal of Epidemiology 25(4): 840-845

[13.] Bulatao, R.A., Lee, R.D., Hollerbach, P.E., and Bongaarts, J.(2003), eds. Determinants of fertility in developing countries. Vol. 2: Fertility regulation and institutional influences. New York, Academic Press, p. 381-414. Byrne, G.(2007) Father may not know best, but what does he know? Population Today 25(10): 1-2 Centre for diseases control and prevention (CDC). HIV/AID surveillance Report, Atlanta, GA, USA: CDC 2000, table1, pp.5 and table 25, pp. 34

[14.] Danforth, N. (Consultant) [Risks of men's gender roles] Personal communication, Aug. 2008.

[15.] Edwards, S.R. The role of men in contraceptive decision-making: Current knowledge and future implications. Family Planning Perspectives 26(2): 77-82. Apr. 2008. 
[16.] Engender Health, Global Issues and Trends, New York: Engender Health, 2009.

[17.] E.O.Orji , C.A.Adegbenro , B.I.Akinniranye , G.O.Ogunbayo , A.E.Oyebadejo (2007). Spousal communication on family planning as a safe motherhood option in sub-saharan African communities.

[18.] Ezeh A.C, Seroussi M and Raggers H (2003) Men's fertility, contraceptive use, and reproductive preferences, Calverton, MD, USA: Macro International, Inc.

[19.] Fatima, N.B. (2001) The plight of rural women. In: Raj, S.L., ed. Quest for gender justice: A critique of the status of women in India. Madras, India, Satya Nilayam Publishers,. p. 12-26.

[20.] Feyisetan B.J. Bamiwuye S.O. (2000). Postpartum counseling and contraceptive use in Nigeria. Ife Soc Science, vol. 15: 30-41

[21.] Feyisetan B.J.(2000) Spousal communication and contraceptive use among the Yoruba of Nigeria. Population Research and Policy vol. 19: 29-45.

[22.] Fortney, J.A., Susanti, I., Gadalla, S., Saleh, S., Feldblum, P.J., and Potts, M(2005). Maternal mortality in Indonesia and Egypt. International Journal of Gynaecology and Obstetrics 26(1): 21-32.

[23.] Freedman R. and Sun T.(2003) Comparison of the reporting of the use of contraception by husbands and wives, as related to their desire for additional children, Taiwan Population Studies Working Paper, Ann Arbor, MI, USA: University of Michigan Population Studies Center, No. 28.

[24.] Grady, W.R., Tanfer, K., Billy, J.O.G., and Lincoln J. (Sep./Oct. 2006) Men's perceptions of their roles and responsibilities regarding sex, contraception and childrearing. Family Planning Perspectives 28(5): 221-226.

[25.] Green, C.P., Cohen, S.I., and Belhadj E.L. Ghouayel, H. (2005) Male involvement in reproductive health, including family planning and sexual health. New York, United Nations Population Fund, Nov. $104 \mathrm{p}$.

[26.] Griffin, D., \& Ringheim, K. (1999). they? Plan Parent Chall(2),

[27.] Heinemann, K., Saad, F., Wiesemes, M., White, S., \& Heinemann, L. (2005). Attitudes toward male fertility control: results of a multinational survey on four continents. Hum Reprod,

[28.] Hollerbach, P.E., and Bongaarts, J., eds.(2004) Determinants of fertility in developing countries. Vol. 2: Fertility regulation and institutional influences. New York, Academic Press, p. 381-414.

[29.] Isiugo-Abanihe, U.C. (May/June2004) Reproductive motivation and family size preference among Nigerian men. Studies in Family Planning 25(3): 149-161.

[30.] Jimoh A.A.G (2003) Utilization of Antenatal services at the provincial hospital, mongumo,. Women's Health and Action Research center (WHARC). Guinea equatorial.

[31.] Jones, J.(2006) Urban fatherhood program. Presented at Johns Hopkins Center for Communication Programs, Baltimore

[32.] Karra, M.,V., Stark, N.N., and Wolf, J.(2007) Male involvement in family planning: A case study spanning five generations of a South Indian family. Studies in Family Planning vol. 28(1): 24-34.

[33.] Koblinsky, M.A., Campbell, O.M., and Harlow, S.D. (2003). Mother and more: A broader perspective on women's health. In: Koblinsky, M., Timan, J., and Gay, J. eds. The health of women: A global perspective. Boulder, Colorado, Westview Press, p. 33-62.

[34.] Kuala Kumpur (1996) Men's role and responsibilities in reproduction. Arroe for change journal.

[35.] Kulu, I.(2000) Husbands as decision-makers in relation to family size: East-west differentials in Turkey. Turkish Journal of Population Studies, Vol. 12.

[36.] Lasee, A. and Becker, S. (March 2007) Husband-wife communication about family planning and contraceptive use in Kenya. International Family Planning Perspectives 23(1): 15-20.

[37.] Lucas A.O, Gilles H.M (2003) Short Textbook of Public Health Medicine for the Tropics. $4^{\text {th }}$ Edition. Malta. Book Power

[38.] Mccauley, A.P., Robey, B., Blanc, A., and Geller, J.(2008) Opportunities for women through reproductive choice. Population Reports, Series M, No. 12. Baltimore, Johns Hopkins School of Public Health, Population Information Program.

[39.] Mekonnen (2003) patterns off maternity care service utilization in southern Ethiopia. Evidence from a community and family survey. Ethiopia journal of health development

[40.] Millennium Development Goal Report (MDG) United Nations Department of Economic and Social Affairs (DESA) July 2009. 
[41.] Morgan SP and Niraula B, (2005). Gender inequality and fertility in two Nepali villages, Population and Development Review, 21(3):541-561.

[42.] Mumford, S. (March 2003) The vasectomy decision-making process. Studies in Family Planning 14(3): 83-88.

[43.] Murphy M, Baba T M. Rural (2005). Dwellers and health care in Northern Nigeria. Soc Sci Med, 15A(3/1):265-271

[44.] National population commission (NPC) Nigeria and ORC macro 2004. Nigeria Demographic and health survey 2003. Calverton, Maryland: National population commission ORC Macro

[45.] National Population Commssion(NPC).The 2006 Population Census of Nigeria. Analytical Report New York Population council 1997

[46.] Nigerian Demographic and Health Survey Fact sheet (2008).

[47.] Odimegwu, Adewuyi, Odebiyi, Aina, Adesina, Olatubera and Eniola ( $3^{\text {rd }}$ December 2005 pp 59-

71) Men's role in emergency obstetric care in osun state of Nigeria Africa journal of reproductive health womens health and Action Research center

[48.] Ogawa, N. and Hodge, R.W. (2003).Fertility and the locus of family control in contemporary Japan. Bangkok, Thailand, Population Division, Economic and Social Commission for Asia and the Pacific, 29 p.

[49.] Ojofeitimi, E.O Ogunjuyigbe O.P, Ayotunde L,(2009). Spousal communication, changes in partner attitude, and contraceptive use among the Yorubas of Southwest, Indian journal of community medicine Vol. 34 Nigeria

[50.] Orji E, Adegbenro C, Akinniranye B, Ogunbayo G, Oyebadejo E (2007) Spousal communication on family planning as a safe motherhood option in sub-saharan African communities. Journal of Chinese Clinical Medicine, vol. 2(6):319-32

[51.] Orji E, Adegbenro C, Olakanmi O, Omolayo T, Olowojure A (2007). men involvement in safemotherhood. J Turkish German Gynecol Assoc. 8(3): 240-248

[52.] Pauliina Aarnio, Agnes Chimbiri, Teija Kulmala (2001) Male involvement in safemotherhood. www.uta.fi/dih/safemotherhood.

[53.] Population Reports. New perspectives on men's participation: An ICPD issue. Volume XXX, Number 2 october, 2008. series J, Number 46

[54.] Raymond, Joseph, Tumwesigye Juliet (2010) Male partner attendance of skilled antenatal care in peri-urban Gulu district, Northern Uganda

[55.] Renne, E. (Nov./Dec. 2003).Gender ideology and fertility strategies in an Ekiti Yoruba village. Studies in Family Planning 24(6): 343-353.

[56.] Robey, B. and Drennan, M.(2008) Male participation in reproductive health Network (Family Health International) vol. 18

[57.] Roudi, F. and Ashford, L.(2006) Men and family planning in Africa. [chart book of DHS data] Washington, DC, Population Reference Bureau.

[58.] Sharma, R. and Desai, S. (Apr./Jun. 2002) Vitamin A in pregnancy: A review. Indian Journal of Maternal and Child Health 3(2): 36-40.

[59.] Sherpa, H. and RAI, D. (2004) Safe motherhood: It is a family responsibility. Report on national Safe Motherhood Awareness Campaign. Kathmandu, Nepal, Centre for Development and Population Activities. 72 p.

[60.] Suvi kupari(2005): Acess and attitudes towards antenatal care and skilled birth attendance in oyo state, Nigeria Public Health Exchange report. Collage of medicine, university of Ibadan, Nigeria

[61.] Thaddeus, S. and Maine, D.(2004) Too far to walk: Maternal mortality in context. Social Science and Medicine 38(8).

[62.] UNDP/UNFPA/WHO/World Bank special programme of research, development and Research training in human reproduction. (2004). Nigeria men seek status and security through large families. Progress in human reproduction research; 32: 2-4

[63.] United Nations Development Programme (UNDP). (2005) Human development report: Consumption for human development. Geneva.

[64.] United nations fund for children (UNICEF).(2007) The role of men in the lives of children. New York, UNICEF, Dec. vol 39 
South American Journal of Nursing

Special Edition 2016

[65.] United Nation (UN) Report of the international conference on population and Development, Cario, 5-13 September, 2004, New York: UN, 2004.paragraphs.4, 24 and 4, 29 pp. 300-31

[66.] Wambui, Catherine. (2005). Parents, Kenya: Male Only Centers: A New Concept in Family Planning, published in Conveying Concerns: Women Write on Male Participation in the Family. Publications of the Women's Edition Project, Population Reference Bureau, Inc.

[67.] Westoff, C.F. and Bankole, A. The time dynamics of unmet need: An example from Morocco. International Family Planning Perspectives 24(1): 12-14, 24. Mar. 2008.

[68.] Wilkinson, D., Ward, V., Landry, E., and Behrman, L. (March 2002) Vasectomy decision-making in Kenya. New York, AVSC International, 32 p.

[69.] World Health Organization(WHO) and United Nations Children Fund(2008). Estimates of maternal mortality.A new approach by WHO and UNICEF. Geneva.

\section{Appendix}

Dear respondents,

I am a student of community health in Obafemi Awolowo University Ile -Ife conducting a research on Involvement of males in utilization of maternity care service by their spouses. You have been selected to participate in this study I thereby solicit for your sincere response to the under listed questions. Your response shall be used for research purposes only. Thanks.

\section{Questionnaire}

\section{Section a: demographical characteristics}

1. Age at last birthday (in years):

2. Ethnicity: a. Yoruba \{\} b. Hausa \{\} c. Igbo \{\} d. Others (specify)

3. Religion: a. Christianity \{\} b. Islam \{ \} c. Traditional \{ \} Others-

4. Educational Status: a. None \{\} b. primary \{\} c. Secondary \{\} d. Tertiary \{\}

5. Number of wife (ves)

6. Number of living children

7. Age of your last child

\section{Section b: knowledge on maternity care}

8. To what extent do you agree that the following services are components of maternity care

$\mathrm{SA}=$ STRONGLY AGREE, $\mathrm{A}=\mathrm{AGREE} \mathrm{D}=$ DISAGREE $\mathrm{SD}=\mathrm{STRONGLY} \mathrm{DISAGREE}$ $\mathrm{U}=\mathrm{UNDECIDED}$

\begin{tabular}{|l|l|l|l|l|l|l|}
\hline & SA & A & D & SD & U \\
\hline sA & Reproductive health counseling & & & & & \\
\hline b. & Prenatal care & & & & & \\
\hline c. & Promotion of maternal nutrition & & & & & \\
\hline d. & Skilled assistance during childbirth & & & & \\
\hline e. & Care for obstetric complications & & & & & \\
\hline f. & Management of obstetric emergencies & & & & \\
\hline g. & Postpartum care & & & & & \\
\hline h. & Management of abortion complications & & & & \\
\hline k. & Family planning counseling, information and services & & & & & \\
\hline 1. & Reproductive health education & & & & & \\
\hline
\end{tabular}

\section{Section c: roles of men in maternity care.}

9. To what extent do you agree that the following are roles of men in different aspects of maternity care services: 
9.1 PRENATAL CARE

\begin{tabular}{|c|c|c|c|c|c|c|}
\hline & & $\begin{array}{l}\mathrm{S} \\
\mathrm{A}\end{array}$ & A & $\mathrm{D}$ & $\begin{array}{l}\mathrm{S} \\
\mathrm{D}\end{array}$ & $\mathrm{U}$ \\
\hline a. & Ensure that the pregnant mother gets proper antenatal care & & & & & \\
\hline $\mathrm{b}$ & $\begin{array}{l}\text { provide transportation or funds to pay for pregnant mother } \\
\text { antenatal visits }\end{array}$ & & & & & \\
\hline c. & $\begin{array}{l}\text { Accompany the pregnant mother on the antenatal visits, where } \\
\text { you learn about normal changes that occur during pregnancy } \\
\text { as well as danger signals of pregnancy complications. }\end{array}$ & & & & & \\
\hline $\mathrm{d}$ & Ensure that spouse receives good nutrition and adequate rest. & & & & & \\
\hline e. & $\begin{array}{l}\text { Taking active role in working out a plan for delivery of the } \\
\text { baby. }\end{array}$ & & & & & \\
\hline f. & $\begin{array}{l}\text { Ensure that spouse receives appropriate immunization during } \\
\text { pregnancy }\end{array}$ & & & & & \\
\hline $\mathrm{g}$ & $\begin{array}{l}\text { Ensure that spouse receives malaria prophylaxis or treatment } \\
\text { during pregnancy. }\end{array}$ & & & & & \\
\hline $\mathrm{h}$ & $\begin{array}{l}\text { Learning the symptoms of imminent delivery and of delivery } \\
\text { complications. }\end{array}$ & & & & & \\
\hline
\end{tabular}

9.2 DELIVERY

\begin{tabular}{|l|l|l|l|l|l|l|}
\hline & & SA & A & D & SD & U \\
\hline a. & Ensuring that delivery is taken by trained attendant & & & & & \\
\hline & Paying for the delivery services. & & & & & \\
\hline b. & Paying for the services rendered during childbirth. & & & & & \\
\hline c. & Arranging ahead of time for transportation. & & & & \\
\hline d. & Avoiding delays in deciding and seeking health care & & & & & \\
\hline e. & $\begin{array}{l}\text { Supporting spouse psychologically during delivery by } \\
\text { staying with her. }\end{array}$ & & & & & \\
\hline
\end{tabular}

9.3 POSTNATAL

\begin{tabular}{|l|l|l|l|l|l|l|}
\hline & & SA & A & D & SD & U \\
\hline a. & $\begin{array}{l}\text { Helping spouse with heavy household works especially } \\
\text { during postnatal period }\end{array}$ & & & & & \\
\hline b. & $\begin{array}{l}\text { Ensuring that your children receive all of the needed } \\
\text { immunizations. }\end{array}$ & & & & \\
\hline
\end{tabular}

9.4 FAMILY PLANNING

\begin{tabular}{l|l|l|l|l|} 
SA & A & D & SD & U \\
\hline
\end{tabular}


South American Journal of Nursing Special Edition 2016

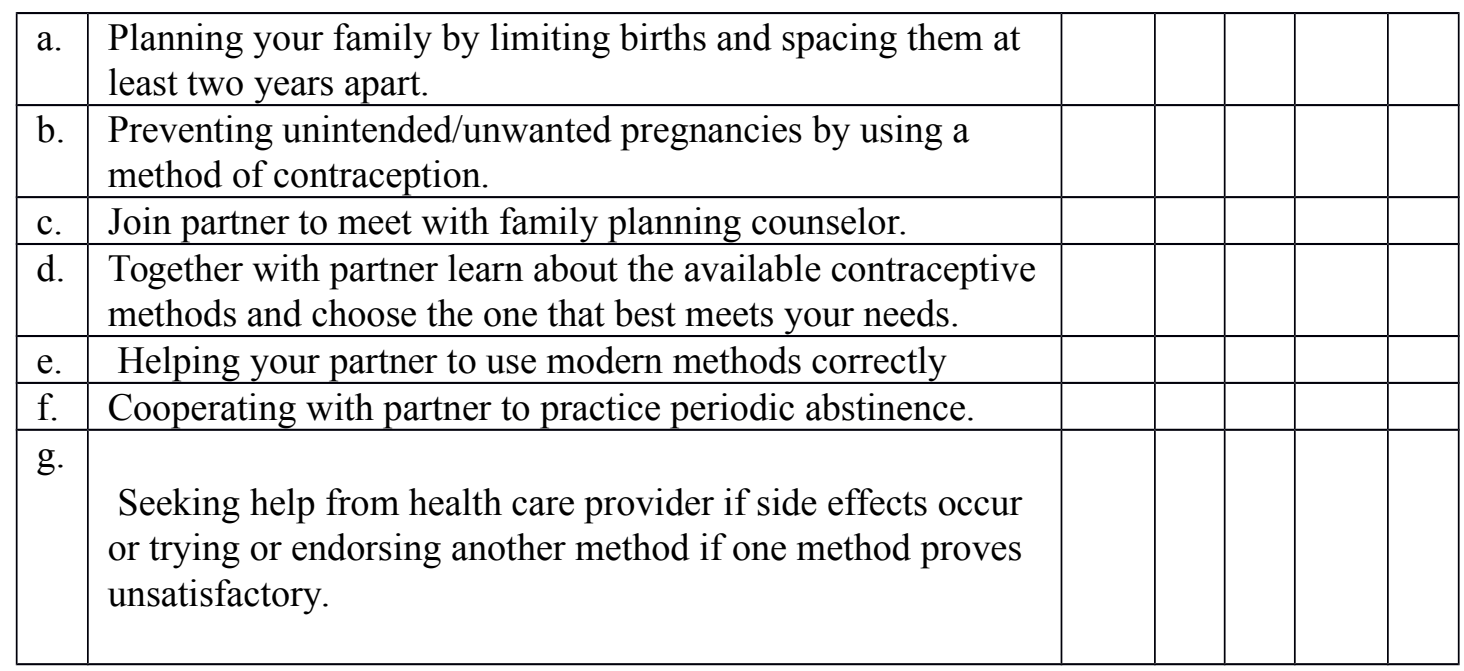

10. How often do you carry out the following roles relating to maternity care at family level? :

\begin{tabular}{|c|l|l|l|l|}
\hline & & All the time & Sometimes & Never \\
\hline a. & Promotion of maternal nutrition & & & \\
\hline b. & $\begin{array}{l}\text { Ensure that mother gets proper care } \\
\text { during pregnancy }\end{array}$ & & & \\
\hline c. & $\begin{array}{l}\text { Helping her with heavy household } \\
\text { works }\end{array}$ & & & \\
\hline d. & $\begin{array}{l}\text { Taking active role in working out a plan } \\
\text { for delivery of the baby }\end{array}$ & & & \\
\hline e. & $\begin{array}{l}\text { Avoiding delays in deciding and seeking } \\
\text { health care }\end{array}$ & & & \\
\hline f. & $\begin{array}{l}\text { Recognition of danger signals in } \\
\text { mothers and seeking early intervention }\end{array}$ & & & \\
\hline g. & Proper involvement in family planning & & & \\
\hline
\end{tabular}

11. How often do you carry out the following roles of men in maternity care at individual level? :

\begin{tabular}{|l|l|l|l|l|}
\hline & & $\begin{array}{l}\text { All the } \\
\text { time }\end{array}$ & Sometimes & Never \\
\hline a. & $\begin{array}{l}\text { Active participation in programs that aim to improve } \\
\text { mothers' health }\end{array}$ & & & \\
\hline b. & Learn and recognize the danger signals in mothers & & & \\
\hline c. & Helping mothers with heavy duties & & & \\
\hline d. & Encourage the mother to seek health care as necessary & & & \\
\hline e. & Aiding in decision making in seeking obstetric care & & & \\
\hline f. & Visiting antenatal clinic with the spouse & & & \\
\hline g. & Being present with the wife during delivery & & & \\
\hline
\end{tabular}

\section{Section d: barriers to male involvement in maternity care}

12. To what extent do you believe that these factors had hindered you from getting involved in maternity care services?

\begin{tabular}{|l|l|l|l|l|l|l|}
\hline & \multicolumn{1}{|l|}{} & SA & A & SD & D & U \\
\hline a. & Lack of access to accurate information about safe motherhood & & & & & \\
\hline b. & Services that is exclusively focused on women & & & & & \\
\hline c. & $\begin{array}{l}\text { Lack of appropriate policy that support men's role e.g. } \\
\text { paternity leave }\end{array}$ & & & & \\
\hline
\end{tabular}




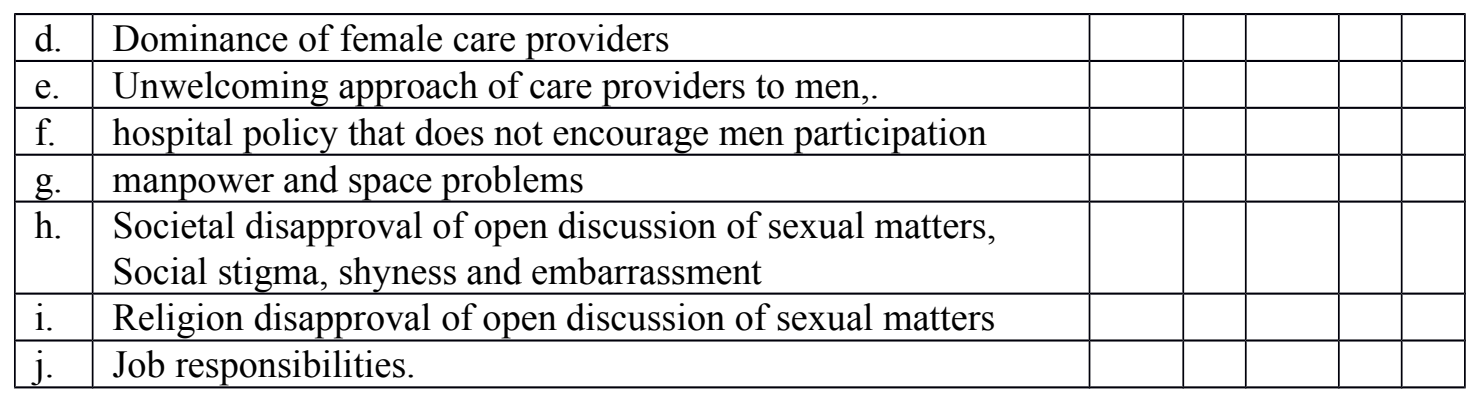

13. Are there other factors that you considered as hindering you from participation in maternal care issues?

(a)

(b)

(c)

\section{List of occupational groups}

1. Drivers

2. Commercial motorcyclists

3. Traders

4. News paper vendors

5. Barbers

6. Men in various household

7. Teachers

8. Local government workers

9. Tailors

10. Bankers

11. Company officials

12. Furniture makers. 